\title{
Fotografia, currículo e cotidiano escolar
}

\author{
Dirce Djanira Pacheco e Zan * \\ A máquina de fotografar sonhos ainda não \\ foi inventada, \\ embora uma foto possa evocar exatamente a magia e o \\ mistério daquilo que se registra com a câmara, \\ o que dificilmente \\ o texto científico consegue realizar. \\ (Sylvia Novaes, 1998)
}

Resumo: Este texto discute o uso da fotografia como recurso metodológico no estudo do cotidiano de uma escola de Ensino Médio no interior de São Paulo. A pesquisa teve como objetivo central investigar o modo pelo qual o currículo de nível médio se realizava no âmbito da instituição. Além das análises de documentos relativos às reformas curriculares e de materiais levantados no arquivo da escola, a pesquisa valeu-se da metodologia da história oral para investigar as ações dos múltiplos sujeitos envolvidos no processo educativo. A partir do material fotográfico e da observação do cotidiano da escola, foi possível compreender os significados que a instituição possui para cada um deles e os sentidos de suas ações. Neste trabalho, pretendo discutir as possibilidades e os limites de pesquisas que trabalham com o cotidiano escolar apoiadas na metodologia acima referida, bem como o uso da imagem como linguagem privilegiada na coleta de depoimentos dos jovens estudantes.

Palavras-chave: fotografia; história oral; currículo; cotidiano escolar; Ensino Médio.

\section{Photography, curriculum and daily routine at school}

Abstract: This text is about the use of photography as a methodological resource in the study of the daily routine at a high school in a town in the state of São Paulo countryside. The main objective of the research was to investigate the way in which the high school curriculum was experienced in the institution. Besides the analysis of the documents related to the curriculum reforms and the material from the school records, the Oral History methodology was used in the research, in order to investigate the actions of the multiple subjects involved in the educational process. From the photographic material and the observation of the school daily routine, it was possible to understand the meanings given to each one of them in the institution and the significance of actions. This work is intended to discuss the possibilities and limitations

* Professora do Departamento de Ensino e Práticas Culturais (Deprac) e pesquisadora do Laboratório de Estudos sobre Violência, Imaginário e Formação de Educadores (Violar) da Faculdade de Educação da Unicamp. Campinas, SP, Brasil. dircezan@unicamp.br 
of studies including the use of daily routines at schools, based on the Oral History methodology. It also brings a discussion on the use of images as a privileged kind of language when collecting information from young students.

Key words: photography; oral history; curriculum; daily routine at schools; high school.

Afinal, o que é a fotografia? Que usos ela possibilita ao pesquisador em trabalhos investigativos em áreas como a educação? Essas são perguntas que nortearão o texto aqui apresentado.

Dubois (1993), ao retomar o histórico da fotografia, apresenta diferentes concepções e referenciais para sua definição e compreensão. No século XIX a fotografia foi considerada como a "imitação mais perfeita da realidade" (p. 27), o espelho do real, enquanto o fotógrafo, para os críticos da época, não passava de um assistente da máquina. Tal concepção está inserida num contexto de reações dos artistas contra o domínio dos novos meios técnicos de reprodução da arte, contra o afastamento da criação e do criador, "[...] contra a fixação no 'sinistro visível' em detrimento das 'realidades interiores' e das 'riquezas do imaginário', e isso justamente no momento em que a perfeição imitativa aumentou e objetivou-se.” (p. 28, grifos do autor). A fotografia, nesse período, era vista como um documento, como memória do real.

Já no século XX, insiste-se mais, segundo Dubois (1993), na ideia da transformação do real pela foto, ou seja, entende-se que a foto é codificada. Portanto, pode-se afirmar que "[...] a significação das mensagens fotográficas é de fato determinada culturalmente, que ela não se impõe como uma evidência para qualquer receptor, que sua recepção necessita de um aprendizado dos códigos de leitura [...].” (p. 41-42). Nesse sentido, a foto passa a ser reconhecida como reveladora de uma verdade interior, de aspectos culturais que passam a ser traduzidos a partir da imagem fotográfica.

Segundo Martins (2002), existem dimensões, significações e determinaçôes ocultas na realidade fotografada que demandam dos pesquisadores decifrar o que se esconde por trás do visível e do fotografável. A fotografia pode ser entendida, segundo o autor, como meio de compreensão imaginária da sociedade. (p. 224). A realidade apresentada pela imagem fotográfica, afirma o autor, "[...] não é mais ela mesma, e sim uma realidade mediada pelo tempo da fotografia, pelo olhar e pela situação social do próprio fotógrafo, por aquilo que ele socialmente representa e pensa [...].” (p. 225).

A fotografia contribui para a ampliação do olhar daquele que fotografa, ou seja, "[...] é capaz de ressaltar aspectos do original que escapam ao olho e são apenas passíveis de serem apreendidos por uma objetiva que se desloque livremente a fim de obter diversos ângulos de visão.” (Benjamin, 1980, p. 7). 
Partindo do reconhecimento desse potencial do ato fotográfico foi que, em uma pesquisa realizada na Escola Estadual Jardim Amanda II, no município de Hortolândia (SP), optou-se por utilizar a máquina fotográfica. Esse uso deu-se com o objetivo de apreender o olhar e a percepção de jovens estudantes do Ensino Médio acerca das mudanças curriculares que ocorriam na escola naquele momento. Essas mudanças davam-se num contexto de reformas educacionais e curriculares no país.

Durante os anos 1990 foram publicados, pelo Ministério da Educação do Brasil, documentos curriculares que propunham reorientar o currículo nas escolas brasileiras. Partindo da análise daqueles documentos e da observação do cotidiano escolar, buscava-se compreender de que modo o currículo se efetivava em uma escola pública do Estado de São Paulo.

A escola selecionada para a investigação está situada em um município próximo a Campinas (SP), marcado, quando da realização da pesquisa, pela presença de uma população pauperizada, pela carência de infraestrutura e de serviços urbanos básicos e por altos índices de violência.

Ao propor a investigação em uma escola de Ensino Médio com tais características, deparei-me com uma população jovem que, além das condiçôes precárias e violentas que enfrentava no seu cotidiano, convivia com a situação de vulnerabilidade social que tem atingido a maior parte da população na faixa etária dos 15 a 24 anos no nosso país. Os estudantes daquela escola estavam, na sua maioria, desempregados ou inseridos em condiçôes de trabalho informais, sem registro ou qualquer direito trabalhista garantido. Sendo assim, a escola selecionada mostrou-se como um espaço permeado pelos conflitos sociais típicos de periferias das grandes cidades brasileiras, portanto, um local significativo para um estudo como o que se objetivava naquele momento.

Para esse estudo fiz a opção pela metodologia da história oral devido às possibilidades que ela traz ao pesquisador de, além de contribuir para a construção/reconstrução da identidade histórica dos sujeitos, empreender um esforço que possibilite o afloramento da pluralidade de visōes inerentes à vida coletiva (Neves, 2000).

Para compreender a dinâmica e os diferentes conflitos presentes na realidade do bairro e no cotidiano da EE Jardim Amanda II, suas relaçôes com questões sociais mais amplas e a forma como o currículo se constituía naquele contexto, foram utilizados diferentes instrumentos de pesquisa, com a expectativa de que a multiplicidade e a diversidade desses instrumentos pudessem corroborar uma análise mais profunda da realidade.

Através das observações e da reflexão sobre os dados coletados, foi iniciado um trabalho de registro de entrevistas com professores que atuavam na escola. Os depoimentos foram colhidos a partir de um mesmo roteiro que orientou o 
diálogo com todos os entrevistados. As questôes não foram seguidas de forma rígida, mas formuladas com a intenção de estimular o entrevistado a discorrer a partir das informações que detinha sobre os temas propostos e de interesse para a investigação.

Colocava-se, então, outro problema: a necessidade de registrar as falas e as percepções dos alunos sobre a escola, o currículo, o trabalho dos professores, sobre eles mesmos e o mundo em que viviam. Com essa intenção, iniciou-se uma aproximação com os estudantes através de uma atividade que pudesse criar uma espécie de estímulo inicial: foi solicitado a um grupo de alunos que fotografasse a escola. Essa atividade, acreditava-se naquele momento, teria grande importância para a coleta de dados acerca da realidade estudada. O objetivo era, partindo das fotos, entrevistar os alunos, problematizando as imagens por eles registradas, entrando em contato com a escola a partir da visão desses estudantes, e dos aspectos por eles selecionados; buscando, assim, compreender os sentidos que eles próprios atribuíam àquela realidade.

O grupo de alunos foi formado por um representante de cada classe do Ensino Médio do período matutino. Os integrantes foram escolhidos a partir de observações durante o acompanhamento das aulas e por indicação de alguns professores. Foram selecionados 15 estudantes do Ensino Médio $(7$ da primeira série; 5 da segunda e 3 da terceira série) do período matutino, mas, ao final, 13 participaram efetivamente do trabalho.

Num primeiro momento, em reunião realizada com os estudantes, foi explicado o objetivo da pesquisa e apresentada a proposta para a participação do grupo. Foram distribuídas duas câmeras aos estudantes e dadas algumas explicaçōes iniciais sobre como usá-las, combinando que poderiam, individualmente, realizar seis fotos. Quando terminassem, repassariam a máquina para outro colega.

Importante ressaltar a intimidade que esse grupo, desde o início, demonstrou com a máquina fotográfica. Rapidamente os estudantes se apropriaram daquele instrumento e demonstraram razoável habilidade no seu manuseio. Do total de fotos produzidas, praticamente todas foram aproveitadas, ou seja, poucas foram perdidas em função da excessiva exposiçãao à luz, da distorção de imagens ou da pouca definição do foco. De certo modo, isso nos revela como esse grupo social mais jovem está imerso numa sociedade em que cada vez é mais central o papel da imagem (Kellner, 1998) e que, talvez por isso, tenham a câmera fotográfica assimilada e incorporada em suas práticas cotidianas.

Apesar da solicitação para que fotografassem individualmente a escola, os estudantes organizaram-se em grupos, juntando-se a colegas que não estavam inseridos entre os 13 alunos, fazendo, assim, seus registros, o que tornou muito mais enriquecedor o material coletado ao final. 
O importante a destacar aqui foram os usos que fizeram da câmera fotográfica. No arquivo, constituído por 75 fotos, 32 visavam denunciar as precárias condições em que se encontrava a escola e 3 retratavam essas mesmas condições no bairro. Doze fotos apontavam para problemas presentes na escola, tais como o uso de drogas, a corrupção e as pichações, e três problematizavam o caráter disciplinador da instituição escolar. Existiam também oito fotos que destacavam os trabalhos desenvolvidos por eles no interior da instituição e que abriam para uma análise acerca das práticas pedagógicas ali presentes. Um número significativo de fotos, 17 , representava os momentos de descontração, grupos de alunos, de professores e funcionários, bem como os espaços de sociabilidade presentes na escola onde costumavam se reunir para conversar, cantar, tocar violão, etc.

No primeiro caso, ao abordarem as condições precárias da escola ou do próprio bairro, muitos dos alunos entrevistados apontavam como causa principal o descaso do poder público para com aqueles que são tratados como números, como estatística. Notava-se, na fala dos alunos, uma indignação sobre a forma como o bairro era desprovido de serviços públicos, de saneamento, de asfalto, etc.

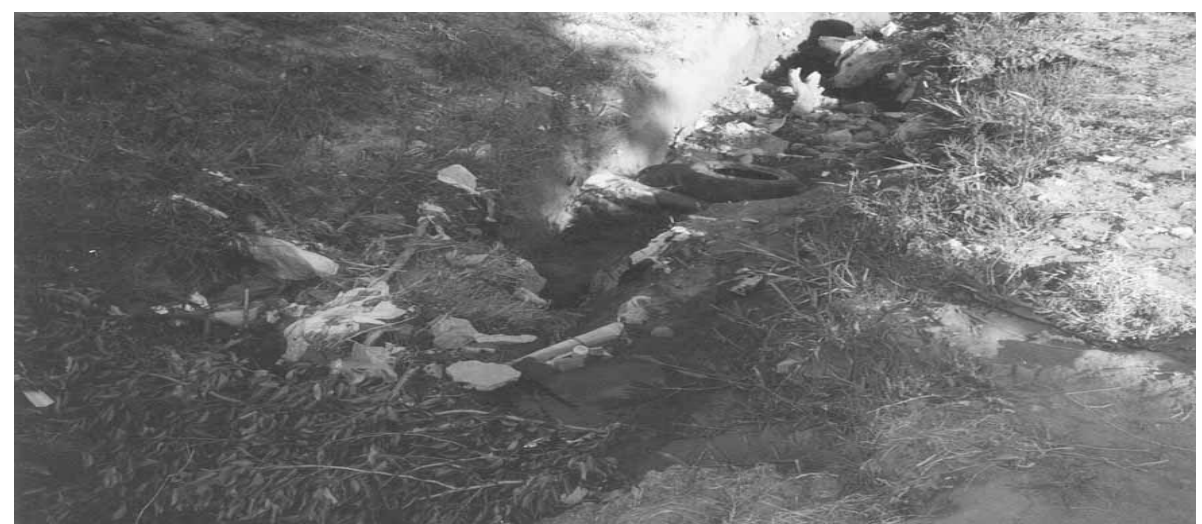

[...] Lá em Hortolândia mesmo, que você tá fazendo o trabalho no Amanda, você pode ir lá qualquer dia que estiver na escola, quando estiver saindo da escola, você passa lá no postinho de saúde para você ver. Éfila, égente chorando, émédico que não tem, éremédio que está em falta, e vem aquele palhaço [se referindo ao ministro da saúde da época] lá falar que a saúde tá melhorando, que nós estamos trabalhando. Também ésó em época de eleição. (Fábio, 18 anos).

Denunciavam a utilização das necessidades e das conquistas do bairro como plataforma política em época de eleição, ofuscando inclusive a história de luta e organização social da população do Jardim Amanda. Apontavam para o fato 
de que as poucas ruas do bairro que foram asfaltadas mais recentemente eram aquelas por onde o ônibus urbano transitava. Denunciaram, a partir das imagens produzidas, a corrupção presente no município e que também atingia a escola. Um desses momentos foi quando três alunos registraram a quadra da escola com os pilares levantados, mas sem a cobertura concretizada. Nas entrevistas disseram - o que também foi confirmado em entrevista com o diretor - que uma empresa havia recebido o pagamento, através de licitação pública do Estado, mas não teria concluído a obra.

A violência que atingia o bairro foi outro tema que surgiu a partir das fotografias feitas pelos estudantes. Ao mesmo tempo que relatavam o medo e a insegurança, apresentavam também formas de sobrevivência a ela: [...] A gente aluga a Sprinter para não ter que ir de ônibus, vai a turminha de sempre, a gente vai sossegada. Não tem confusão. (Maria, 16 anos).

Nesse contexto, foi também apresentada a problemática da droga no interior da escola através de três fotos distintas.
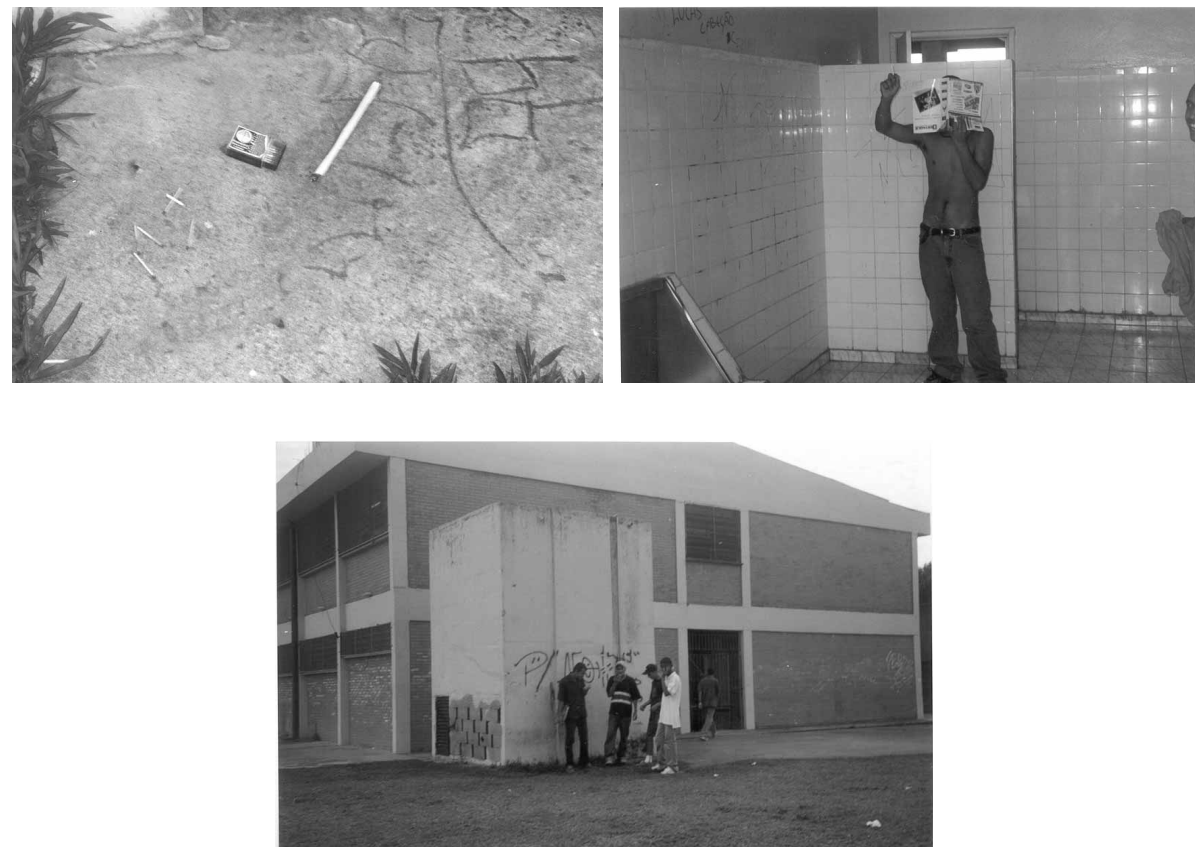

Foi possível perceber que há pontos de vista distintos diferentes entre os alunos acerca do tema: alguns acham que ela está presente na escola, mas que não existe uma ação ostensiva do tráfico; para outros, no entanto, essa presença é agressiva e está associada, muitas vezes, à entrada de armas nas salas de aulas e a atos violentos dentro da instituição. Uma das alunas do grupo de fotógrafos 
procurou abordar aspectos diferentes relativos a essa questão, na tentativa de desmistificar uma relação direta que eventualmente poderia se estabelecer entre droga e pobreza.

Tinha muita briga na escola, tem, eu acho que até hoje muita briga na escola. Eu não sei sobre o que, acho que é a formação de cada um. Porque eu também, às vezes falo: 'ninguém nasce bandido, mas ninguém nasce bandido mesmo!' [...] Droga não é só com pobre, não é só com pessoas que estudam em escola pública não. Isso aí tá meio geral [...]. (Laudicéia, 18 anos).

Foram registradas, em diversas fotos, pichações no interior da escola. Disseram ser, muitas vezes, uma forma de repudiar ou de manifestar-se contra algumas das iniciativas ou posturas dos professores e da direção. Mas disseram também ser essa uma forma de intervenção no espaço do qual queriam se apropriar, colocando nele suas marcas pessoais ou de grupos aos quais pertenciam. Um desses alunos, que se identificou como ex-pichador, ao ver foto de uma de suas pichações na sala de aula assumiu uma postura reflexiva, falando sobre o assunto:

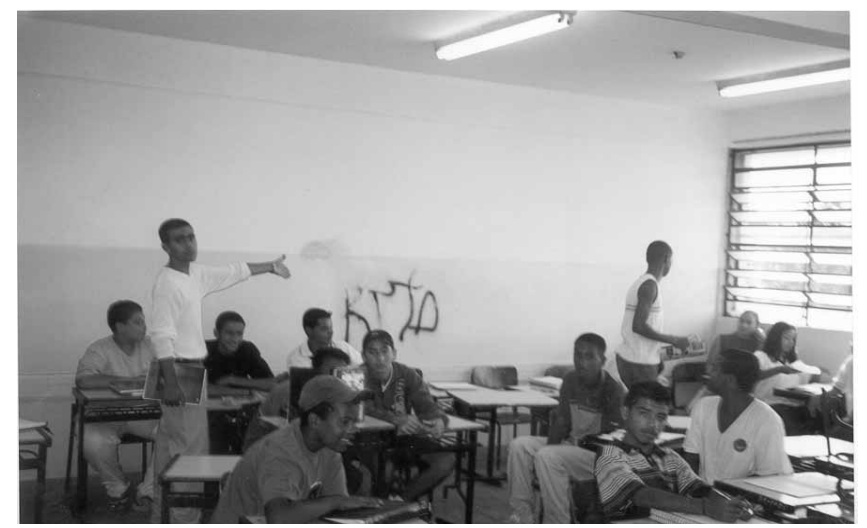

Realmente foi minha. É, sei lá, acho uma grande bobeira. Fiz no final do ano pensando que ia pintar a escola de novo e não fizeram nada. Acabei estragando minha própria escola... Acho que a maioria dos pichadores épara se crescer no meio da galera, para querer ser o maior, ser o melhor, agora tem muitas pessoas [...]. Tipo, quando eu pichava, eu pichava coisas assim que eu sentia, eu tinha vontade de expressar o que eu sentia de uma forma que todos vissem, épor isso que eu pichava [...]. (Bruno, 17 anos).

De certo modo, seu depoimento parece confirmar as análises feitas por Arce (1999) sobre o uso do grafite como forma de afirmar-se, destacar-se perante 
um grupo. Demonstra também a necessidade que esse, como tantos outros jovens, tem de expressar-se e a falta de espaços que possam ser utilizados para esse fim. Ao mesmo tempo, o aluno fala de um certo arrependimento por ter pichado ou "estragado" a sua escola. Talvez esse fosse um sentimento presente nesse aluno ou uma fala construída na tentativa de justificar seu ato perante a pesquisadora que, na sua visão, poderia não aprovar aquele tipo de intervenção.

Por menos rígidas que fossem as regras disciplinares no interior da escola, até mesmo por falta de funcionários, os alunos percebiam-na como uma instituição marcada pelo que Foucault chamou de "procedimentos de poder", ou seja, pelo enclausuramento e pela vigilância. Numa das imagens, apresentavam a fachada do prédio e então me explicaram por que a EE Jardim Amanda II é conhecida entre eles e os outros jovens do bairro como presídio. Destacaram os muros altos, a arquitetura similar à de instituições penitenciárias e as grades que separam espaços e corpos como os maiores exemplos desses procedimentos.
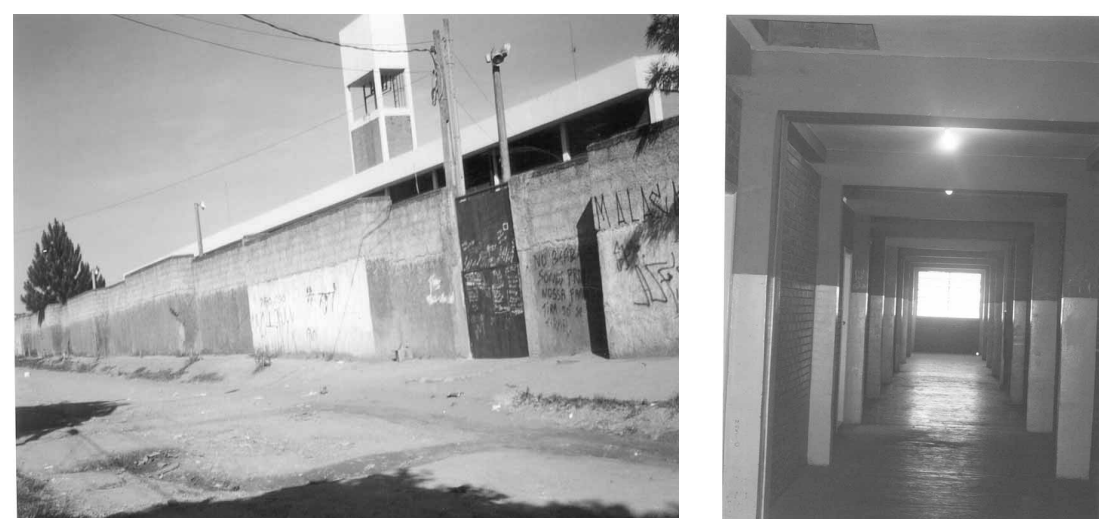

Voltando-se para o espaço interno, também demonstravam como o princípio do controle se fazia presente, ao se construírem os espaços escolares visando impedir ou dificultar o encontro, a interação, na busca de vigiar as pessoas e conduzi-las a um único destino: a sala de aula. "Através dos corredores, - diz Dayrell, ao analisar outra realidade escolar semelhante a essa - chega-se às salas de aula, o locus central do educativo" (Dayrell, 1999, p. 147). No entanto, os alunos subvertiam essa lógica e apropriavam-se desses espaços, transformando-os em ponto de encontro para "conversar, paquerar, zoar". Era frequente a presença de grupos nos corredores da escola, mesmo em períodos de aula.

Utilizaram-se da câmera fotográfica também para denunciar o descaso e a omissão da administração escolar. Através da imagem de um amontoado de carteiras quebradas ao final de um corredor ou de outras que registravam as precárias condiçôes das salas de aulas ou dos banheiros, os estudantes abordaram a questão da rotatividade de professores e da falta de compromisso daque- 
les que passaram pela direção da escola nos últimos anos. É o que foi registrado por um dos alunos, ao fotografar o carro do diretor saindo do estacionamento da escola: $E$ aqui foi o grande flagrante do dia, o diretor indo embora no meio do expediente, a foto do carro dele. Infelizmente não dá para ver que é ele, mas ele estava saindo fora no horário do expediente. (Sérgio, 19 anos).

A sensação desses alunos era de abandono, tanto pelo poder público quanto por aqueles que administravam e deveriam garantir-lhes condições mais adequadas de estudo.

Através das fotos produzidas, os alunos teceram análises também sobre o trabalho pedagógico. Ao fotografar o quadro negro com a "lição de matemática", Murilo denunciava a presença de um ensino sem sentido e pautado pela repetição. Foi além quando, no seu depoimento, teve o cuidado de não responsabilizar individualmente a professora, embora apontasse para a percepção de uma precária formação dos profissionais. Na EE Jardim Amanda II, todos os professores eram titulados nas especificidades com as quais trabalhavam; no entanto, as deficiências de formação eram várias, desde a perspectiva metodológica até mesmo ao domínio do conhecimento do campo específico com o qual trabalhavam. Na sua quase totalidade, esses professores cursaram suas licenciaturas em período noturno e em instituições privadas. A fragilidade decorrente de uma política de massificação da formação de professores era sentida pelos alunos:

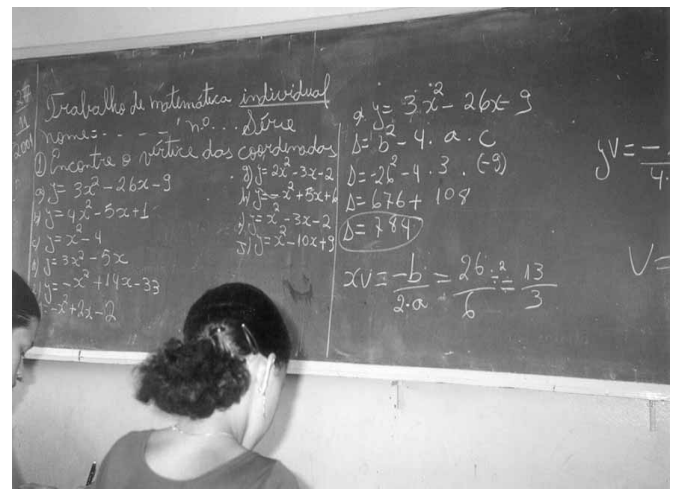

Essa aula aqui [referindo-se à fotografia] era bem chata e continua sendo porque é a mesma professora, não vou falar o nome dela. Eu perguntava, só que ela não sabia responder pra que servia, mas ela é uma boa professora, só que não está também bem qualificada pra dar aula [...] eu acho [...]. (Murilo, 16 anos).

Em outros momentos, os estudantes destacaram iniciativas de trabalho coletivo em busca de um conhecimento mais significativo e que, no entanto, não 
tinha continuidade, perdia-se no vazio, na ausência de projeto para a instituição escolar. Um desses episódios está registrado na fotografia de Charles:

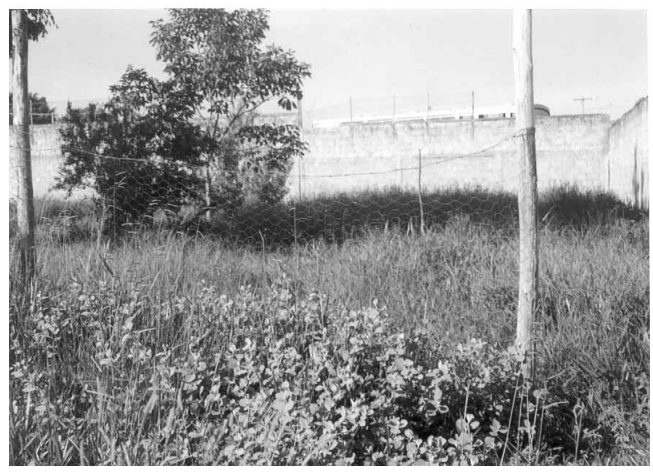

Era pra ser uma horta [referindo-se à foto], começaram o trabalho, inclusive nós alunos ajudamos no comę̧o, só que [...]. Tava valendo ponto em todas as disciplinas pra quem estivesse colaborando. Era uma forma de utilizar o espaço da escola [...]. Fazia a horta, o que fosse produzido ali eles pegavam e faziam a merenda pra gente só que [...]. Sei lá, abandonaram, esqueceram. Aí o mato tomou conta [...]. Trabalho que foi perdido! As horas de estudo que era pra estar aprendendo matéria dentro da sala [...]. Foi tudo por água abaixo! (Charles, 17 anos).

Ao mesmo tempo é importante destacar a quantidade de imagens que mostram os colegas em situaçōes de descontração, grupos de jovens sorridentes, abraçados, fazendo poses e gestos. Na fala de um deles, essa foi uma opção para não mostrar o descaso da escola, mas sim as pessoas, porque para mim o que faz a escola são as pessods, não o prédio. (André, 16 anos).

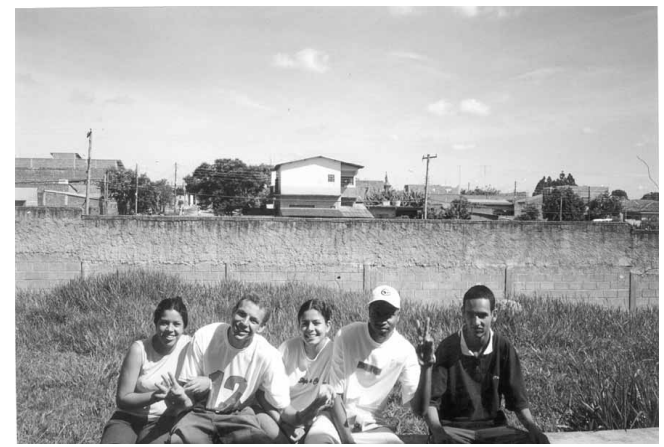



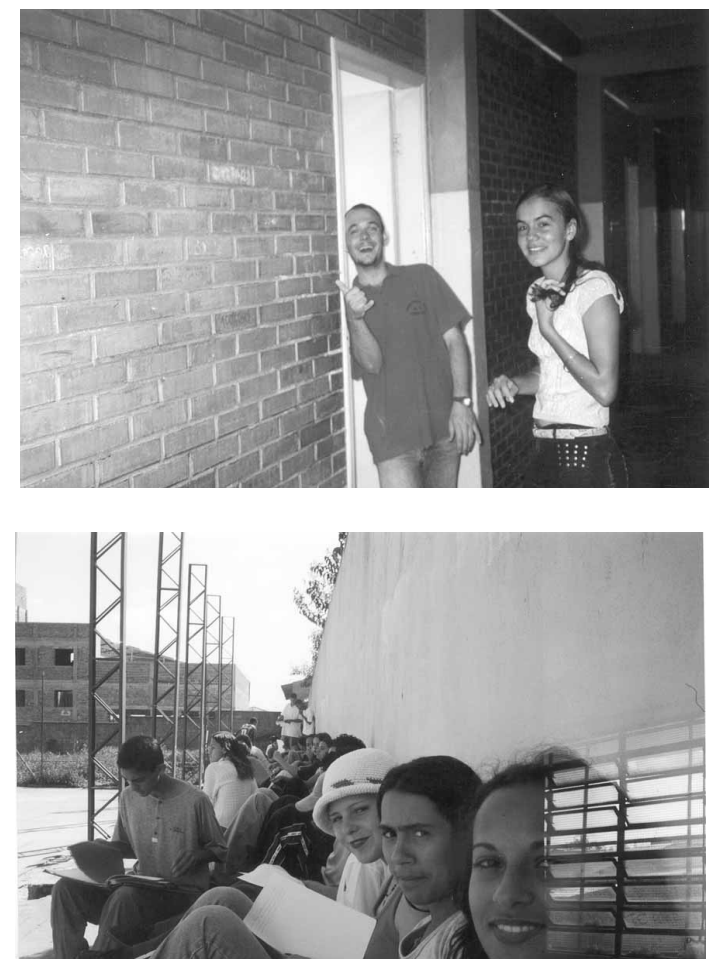

Essa também pode ter sido uma forma de os alunos apontarem para a importância da escola, principalmente em bairros periféricos como o Jardim Amanda, como espaço de sociabilidade, espaço que proporciona o encontro entre eles em situações de relativa segurança. Eram frequentes cenas de agrupamentos daqueles estudantes em torno de um colega tocando violão, quer reunidos no pátio interno do prédio ou sentados nos bancos cimentados embaixo de árvores, conversando ou jogando cartas. A importância desse encontro está também na possibilidade de aprender a conviver, de adquirir conhecimentos e saberes que estão para além do conhecimento científico.

A escola? É quase tudo na vida da gente, porque sem ela eu acho que não seríamos quase nada. Aquié onde se aprende quase tudo na sua vida. Não só a questão de aprendizado, mas sim a questão de convivência. A gente convive com outras pessoas totalmente diferentes. Aqui a gente convive com roqueiros, outros são católicos, outros são adventistas e assim vai. A gente aprende aqui a conviver com cada personalidade aqui da escola. (André, 16 anos).

Essa foi uma experiência significativa para esses estudantes e também para esta pesquisa. A motivação que essa atividade gerou entre os alunos pode ser compreendida, em parte, como resultado de uma quebra na rotina da escola, 
por ser uma atividade diferenciada das que normalmente eram solicitadas pelos professores. No entanto, pode também ser representante da oportunidade que esses estudantes vislumbraram de ser ouvidos e poder, então, registrar suas queixas e inquietações. Alguns demonstraram certa surpresa ao deparar-se com a imagem que produziram e ao reconhecerem-se como sujeitos na produção do conhecimento sobre a realidade pesquisada.

Segundo Maresca (1998), a fotografia pertence à oralidade. Para esse autor, a imagem é ainda mais eficaz para suscitar a palavra nas sociedades sem escrita ou, poderíamos afirmar a partir da experiência nessa pesquisa na EE Amanda II, de grupos que pouco são ouvidos acerca de suas impressões, de seus sentimentos e de suas histórias. Essa hipótese é reforçada com os depoimentos dos estudantes e com a constituição de um roteiro temático, através das imagens por eles produzidas, que norteou as análises da pesquisa.

Mais do que indicações de questôes relevantes a serem abordadas na pesquisa, o ato de fotografar revelou diferentes formas pelas quais os estudantes percebem a realidade escolar, bem como os múltiplos sentidos que atribuem a aspectos específicos da instituição de ensino que frequentam. E tais percepções e sentidos orientam, de certa forma, suas ações que, por sua vez, fazem parte de uma rede de relações que compõe a vida escolar. Portanto, não se pode circunscrever a análise do currículo que se realiza no âmbito da instituição de ensino aos limites dos documentos oficiais e dos programas disciplinares. É preciso compreendê-lo como processo, com um conjunto de práticas marcadas por relações de tensão, conflito, negociação e acomodação que envolve os sujeitos que atuam no ambiente da escola. E os estudantes são parte importante desse jogo.

O uso da fotografia, ao mesmo tempo que contribuiu para a ampliação da percepção dos estudantes em relação ao cotidiano da instituição, permitiu a eles um certo distanciamento em relação aos espaços e às relações vivenciadas de forma rotineira. Esse distanciamento parece ter sido decisivo para que os entrevistados se reconhecessem como sujeitos.

O trabalho com fotografia em pesquisas que tenham como objeto o cotidiano escolar amplia as possibilidades de análise. "As imagens são criação interpretativa que é fruto de um imaginário social, e que, ao mesmo tempo, engendra outros, que podem até mesmo virem a se transformar em realidade." (Novaes, 1998, p. 117). Daí a importância de que os sujeitos do próprio grupo investigado sejam aqueles a fazer uso da câmera, indicando o que desejam ver figurar em suas imagens, o que lhes parece ser significativo para ser analisado. A imagem, seja fotográfica ou não, pela especificidade de sua linguagem mais flexível que o texto, "[...] acomoda em sua estrutura narrativa múltiplos significados, sendo, portanto, um elemento essencial para que se possa analisar como estes significados são construídos, incutidos e veiculados pelo meio soci- 
al [...]." (Novaes, 1998, p. 117), ampliando dessa forma, os desafios do pesquisador.

Segundo Benjamin, no mundo capitalista moderno, a reconstrução da experiência deve ser acompanhada de uma nova forma de narratividade, ou seja, na impossibilidade de retomada de uma narrativa espontânea, oriunda de uma organização comunitária centrada no artesanato, podem emergir formas sintéticas de experiência e narratividade. Nesse sentido, pode-se afirmar que os fragmentos apresentados por esse grupo de jovens possibilitam a construção de uma narrativa que nos leve a entrar em contato com questóes presentes no mundo atual, principalmente no contexto daqueles sujeitos que habitam as periferias dos grandes centros. Ampliam o espectro de análises, ao apresentarem trechos, episódios de histórias e percepções, uma abertura para a pluralidade de sentidos e interpretaçôes que venhamos a fazer.

\section{Referências bibliográficas}

ARCE, José Manuel Valenzuela. Vida de barro duro: cultura popular juvenil e grafite. Rio de Janeiro: Editora UFRJ, 1999.

ARROYO, Miguel. Experiências de inovação educativa: o currículo na prática da escola In: MOREIRA, Antônio Flávio (Org.) Currículo: políticas e práticas. Campinas: Papirus, 1999.

BENJAMIN, Walter. Textos escolhidos. In: Os pensadores. São Paulo: Abril Cultural, 1980.

DAYRELL, Juarez. A escola como espaço sócio-cultural. In: DAYRELL, Juarez. (Org.) Múltiplos olhares sobre educação e cultura. Belo Horizonte: Ed. UFMG, 1996.

DUBOIS, Philippe. O ato fotográfico. Campinas: Papirus, 1993.

FOUCAULT, Michel. O sujeito e o poder. In: RABINOW, Paul; DREYSUS, Hubert. Michel Foucault: uma trajetória filosófica. Rio de Janeiro: Forense Universitária, 1995.

KELLNER, Douglas. Lendo imagens criticamente; em direção a uma pedagogia pós-moderna. In: SILVA, Tomaz Tadeu da (Org.). Alienígenas na sala de aula. Petrópolis: Vozes, 1998.

MARESCA, Sylvain. Olhares cruzados. Ensaio comparativo entre as abordagens fotográfica e etnográfica. In: SAMAIN, Etienne (Org.). O fotográfico. São Paulo: Hucitec/CNPq, 1998.

MARTINS, José de Souza. A imagem incomum: a fotografia dos atos de fé no Brasil. Estudos avançados, São Paulo, v. 16, n. 45, 2002.

NEVES, Lucilia de Almeida. Memória, história e sujeito: substratos da identidade.Revista História Oral, Fortaleza, n. 3, 2000.

NOVAES, Sylvia. O uso da imagem na antropologia. In: SAMAIN, Etienne (Org.). O fotográfico. São Paulo: Hucitec; CNPq, 1998.

Recebido em 30 de março de 2009 e aprovado em 18 de setembro de 2009. 